\title{
Basal-crevasse-fill origin of laminated debris bands at Matanuska Glacier, Alaska, U.S.A.
}

\author{
Stagi L. Ensminger, ${ }^{1}$ Righard B. Alley, ${ }^{2}$ Edward B. Evenson, ${ }^{3}$ Daniel E. Lawson, ${ }^{4}$ \\ Grahame J. LARSON ${ }^{5}$ \\ ${ }^{1}$ Department of Geology and Geography, Northwest Missouri State University, Maryville, Missouri 64468, U.S.A. \\ ${ }^{2}$ Environment Institute and Department of Geosciences, The Pennsylvania State University, University Park, Pennsylvania 16802, U.S.A. \\ ${ }^{3}$ Department of Earth and Environmental Sciences, Lehigh University, Bethlehem, Pennsylvania 18015, U.S.A. \\ ${ }^{4}$ U.S. Army Cold Regions Research and Engineering Laboratory, Anchorage, Alaska 99505, U.S.A. \\ ${ }^{5}$ Department of Geological Sciences, Michigan State University, East Lansing, Michigan 61201, U.S.A.
}

\begin{abstract}
The numerous debris bands in the terminus region of Matanuska Glacier, Alaska, U.S.A., were formed by injection of turbid meltwaters into basal crevasses. The debris bands are millimeter(s)-thick layers of silt-rich ice cross-cutting older, debris-poor englacial ice. The sediment grain-size distribution of the debris bands closely resembles the suspended load of basal waters, and of basal and proglacial ice grown from basal waters, but does not resemble supraglacial debris, till or the bedload of subglacial streams. Most debris bands contain anthropogenic tritium $\left({ }^{3} \mathrm{H}\right)$ in concentrations similar to those of basal meltwater and ice formed from that meltwater, but cross-cut englacial ice lacking tritium. Stable-isotopic ratios $\left(\delta^{18} \mathrm{O}\right.$ and $\left.\delta \mathrm{D}\right)$ of debris-band ice are consistent with freezing from basal waters, but are distinct from those in englacial ice. Ice petrofabric data along one debris band lack evidence of active shearing. High basal water pressures and locally extensional ice flow associated with overdeepened subglacial basins favor basal crevasse formation.
\end{abstract}

\section{INTRODUGTION}

Some glaciers exhibit planar, debris-rich zones often called debris bands. Debris bands supply debris to the glacier terminus above the basal zone, and thus may be important in the development of Rogen (Sugden and John, 1976) or shear moraines (Bishop, 1957; Moran, 1971; Ehlers, 1981), or headsof-outwash sequences where ice has been buried by debris transported to the ice margin by a "conveyor-belt" delivery mechanism (Koteff, 1974; Koteff and Pessl, 1981; Mulholland, 1982; cf. Stewart and MacClintock, 1971). Debris bands may not dominate glacial sediment transport (Weertman, 1961; Boulton, 1970; Hooke, 1973; Evenson and Clinch, 1987; Gustavason and Boothroyd, 1987; Alley and others, 1997b; Ensminger and others, 1999b), but may be an important component, depending on a glacier's thermal regime and other factors (Hambrey and others, 1999). Additionally, debris bands may provide information on the stress-state and deformational processes of glaciers (Glasser and others, 1998).

Debris bands have multiple origins. These include, but may not be limited to: burial of supraglacial debris by snowfall on the glacier surface (Grove, 1960; Hambrey and others, 1999) or in surface crevasses (Hubbard and Sharp, 1995); upward shearing, thrusting or folding of basal material (Goldthwait, 1951; Clarke and Blake, 1991; Hambrey and others, 1996, 1999); and injection into basal crevasses of basal material en masse or carried in water (Mickelson and
Berkson, 1974; Sharp, 1985; Bennett and others, 2000; Roberts and others, 2000). All may be coupled with or followed by varying degrees of folding or other deformation (e.g. Hudleston and Hooke, 1980; Hambrey and others, 1999).

As summarized in Table 1, these different origins produce characteristically distinct debris bands. For example, debris carried into surficial or basal crevasses by wind or water may be well sorted (Hubbard and Sharp, 1995; Ensminger and others, 1999b; Bennett and others, 2000). However, material folded or sheared into basal ice or injected by till deformation into basal crevasses typically will be poorly sorted and include the striated and faceted clasts characteristic of basal zones of many glaciers (Goldthwait, 1951; Clarke and Blake, 1991; Hambrey and others, 1996, 1999; Roberts and others, 2000). Supraglacial rockfalls usually will include angular clasts (Grove, 1960; Hambrey and others, 1999).

Debris sheared into the body of the glacier or buried well up-glacier will be enclosed by ice isotopically similar to other englacial ice, having "normal" accumulation-zone meteoric stable-isotopic ratios and lacking tritium $\left({ }^{3} \mathrm{H}\right)$ from atmospheric atomic-bomb testing. However, if debris is carried into the glacier by meltwaters that then freeze, the ice formed will have stable-isotopic ratios characteristic of growth from the glacial water system, often somewhat heavier than englacial ice, and may have bomb-produced ${ }^{3} \mathrm{H}$ if sufficiently young (Libby, 1955; Leventhal and Libby, 1970; Lawson and Kulla, 1978; Gat, 1980; Strasser and others, 1996; Lawson and others, 1998; Ensminger and others, 1999b). Active localized deformation associated with 
Table 1. A " $Y$ " indicates the observed or hypothesized characteristics of debris bands that result from the different proposed mechanisms of formation. No attempt was made to estimate observed frequency of occurrence. The "Observed" row summarizes the data for this study

\begin{tabular}{|c|c|c|c|c|c|c|c|c|}
\hline Model of origin & $\begin{array}{c}\text { Mechanism of material } \\
\text { incorporation }\end{array}$ & $\begin{array}{c}\text { Basal } \\
\text { connection }\end{array}$ & $\begin{array}{l}\text { Striated } \\
\text { clasts }\end{array}$ & $\begin{array}{c}\text { Well- } \\
\text { sorted } \\
\text { sediments }\end{array}$ & $\begin{array}{c}\text { En masse } \\
\text { basal } \\
\text { materials }\end{array}$ & $\begin{array}{c}{ }^{3} H- \\
\text { enriched }\end{array}$ & $\begin{array}{l}\delta D, \delta^{18} O \\
\text { composition }\end{array}$ & $\begin{array}{c}\text { Shear } \\
\text { petrofabric }\end{array}$ \\
\hline \multirow{4}{*}{$\begin{array}{l}\text { Shear plane }{ }^{1} \\
\text { Englacial }^{2}\end{array}$} & Shear thrusting & $\mathrm{Y}$ & $\mathrm{Y}$ & & $\mathrm{Y}$ & & Englacial & in active/recent ones \\
\hline & Rockfall & & & & & & Englacial & \\
\hline & Folding and foliation & $\mathrm{Y}$ & $\mathrm{Y}$ & & & $\mathrm{Y}$ & Englacial & in active/recent ones \\
\hline & Eolian & & & $\mathrm{Y}$ & & & Englacial & \\
\hline \multirow[t]{2}{*}{ Basal crevasse $^{3}$} & Till injection & $\mathrm{Y}$ & $\mathrm{Y}$ & & $\mathrm{Y}$ & & Englacial & \\
\hline & Water injection & $\mathrm{Y}$ & & $\mathrm{Y}$ & & $\mathrm{Y}$ & Englacial to less negative than englacial & \\
\hline Observed & & $\mathrm{Y}$ & & $\mathrm{Y}$ & & $\mathrm{Y}$ & Englacial to less negative than englacial & \\
\hline
\end{tabular}

${ }^{1}$ Goldthwait (1951); Clarke and Blake (1991); Hambrey and others (1996, 1999); Glasser and others (1998).

${ }^{2}$ Grove (1960); Hubbard and Sharp (1995); Hambrey and others (1999).

${ }^{3}$ Mickelson and Berkson (1974); Sharp (1985); Ensminger and others (1999b); Bennett and others (2000); Roberts and others (2000).

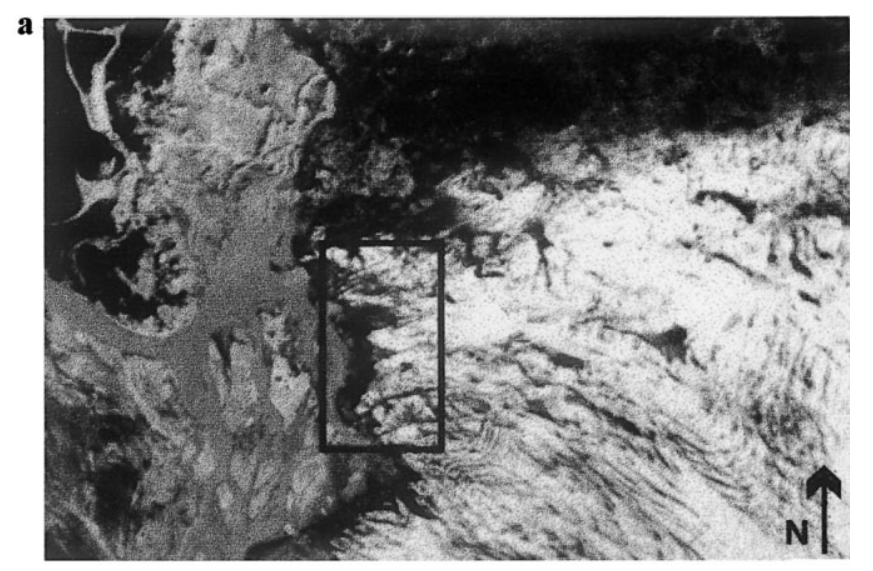

b

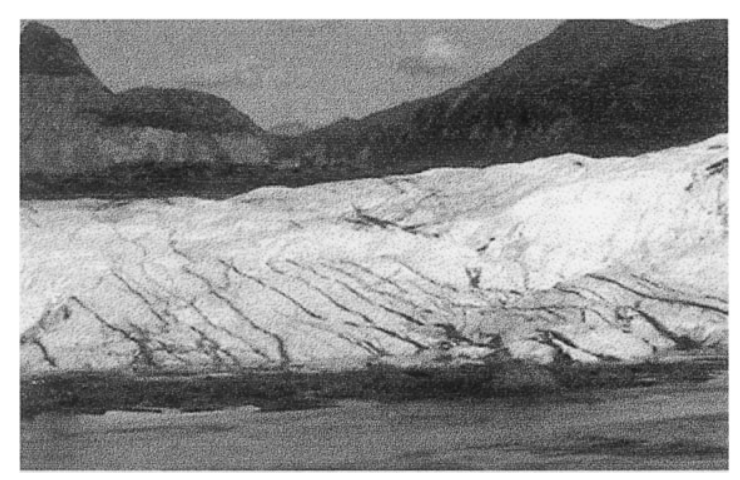

Fig. 1. The western terminus region of Matanuska Glacier. (a) Aerial photograph of the ice margin taken in 1995. At the scale of aerial photography, debris bands are only visible in the boxed portion of the photo. (b) View of boxed area looking eastward in the up-glacier direction. The most prominent debris bands are very nearly parallel to one another and normal to the ice margin.

shearing or folding can be identified through $c$-axis fabrics that differ from those in surrounding ice (e.g. Gow and Williamson, 1976; Budd and Jacka, 1989; Alley, 1992; Alley and others, 1997a).

Matanuska Glacier, Alaska, U.S.A. (Fig. 1), is cut by numerous nearly planar debris bands (in contrast to folded debris bands in some glaciers (e.g. Hambrey and others, 1999) ). To learn the origin of these Matanuska Glacier debris bands, we measured field relations, sediment characteristics, ice-isotopic ratios $\left(\delta^{18} \mathrm{O}\right.$ and $\left.\delta \mathrm{D}\right)$ and composition $\left({ }^{3} \mathrm{H}\right)$ and ice petrofabrics in and adjacent to debris bands, and compared these results to the characteristics summarized in Table 1. We find that the common debris bands of Matanuska Glacier were formed by injection of turbid basal waters into basal crevasses.

\section{ANALYTICAL METHODS}

\section{Field relationships}

General observations on the formation and occurrence of debris bands have been collected during our decades of research at Matanuska Glacier. We visited, sampled and described numerous debris bands, and conducted reconnaissance traverses measuring the locations and orientations of as many debris bands as could be visited safely in an area. Limited radar profiling and drilling have allowed further characterization of the debris bands.

\section{Isotopic composition}

Samples of debris-band ice and surrounding ice were analyzed for ${ }^{3} \mathrm{H}\left(t_{1 / 2}=12.26\right.$ years; Gat, 1980), $\delta^{18} \mathrm{O}$ and $\delta$ D. In August 1996, four different laminated debris bands located within the overdeepened basin near the ice margin were sampled, together with clean, bubble-free englacial ice adjacent to those debris bands. Another of the debris bands split in two near the top of an ice ridge, and samples were collected from both limbs, as well as from the clean, bubbly englacial ice between (Fig. 2). Bulk samples were completely melted, with $30 \mathrm{~mL}$ of meltwater collected for $\delta^{18} \mathrm{O}$ and $\delta \mathrm{D}$ analysis, and $250 \mathrm{~mL}$ collected for enriched ${ }^{3} \mathrm{H}$ analysis. During October 1997, higher-resolution sampling $(2 \mathrm{~cm}$ resolution for stable isotopes, $6 \mathrm{~cm}$ for enriched ${ }^{3} \mathrm{H}$ ) was conducted in a similar way across one debris band.

Electrolytic enrichment and scintillation counting techniques (Kessler, 1988) were used to analyze samples for ${ }^{3} \mathrm{H}$ content at the low-level ${ }^{3} \mathrm{H}$ laboratory at Michigan State University. The analytical detection limit is $1 \mathrm{TU}$ (tritium unit) with a precision of \pm 1 TU. Coastal Scientific Laboratories (Austin, TX) conducted preliminary stable-isotopic analyses with reported precision of $\pm 0.3 \%$ o for $\delta^{18} \mathrm{O}$ and $\pm 5.0 \%$ or for $\delta$ D. Mountain Mass Spectrometry (Evergreen, $\mathrm{CO})$ analyzed high-resolution $\delta^{18} \mathrm{O}$ and $\delta \mathrm{D}$ samples with reported precision of $\pm 0.02 \%$ and $\pm 0.20 \%$, respectively. 


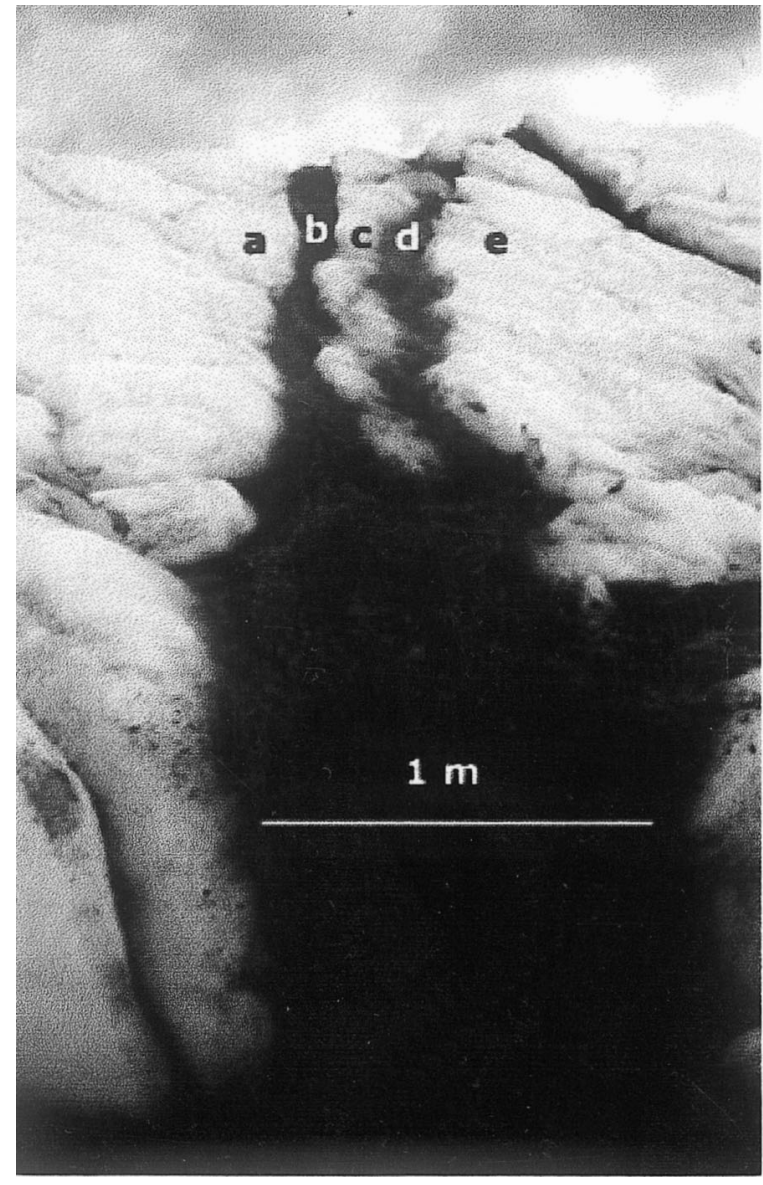

Fig. 2. Laminated debris band as it appears during the summer months. Debris band splits near the center of the photograph. ${ }^{3} \mathrm{H}$ concentrations at each sample location are: (a) $0.5 \mathrm{TU},(b)$ $5.4 \mathrm{TU},($ c) $0.5 \mathrm{TU}$, (d) $7.9 \mathrm{TU}$, (e) $0.3 \mathrm{TU}$. Only the laminated debris-band ice samples are enriched with the ${ }^{3} \mathrm{H}$ relative to englacial ice. The width of the debris band near the bottom center of the photograph is exaggerated by sediment flowage.

\section{Sediment grain-size}

Grain-size analyses were carried out on the sediments in the dirty ice of the debris bands following the methods of Folk (1974). Samples were split to approximately $40-50 \mathrm{~g}$, then wet-sieved through a $4 \phi(62 \mu \mathrm{m})$ screen. The dispersion step was skipped, because previous detailed studies at Matanuska Glacier have shown the clay content to be $<3 \%$ (Lawson, 1979). Sand $(-1 \phi$ to $4 \phi)$ and gravel $(-4 \phi$ to $-1 \phi)$ sizes were dried and sieved at $1 \phi$ intervals $(-2.75 \phi$ and $-3.75 \phi$ were substituted for $-3.0 \phi$ and $-4.0 \phi$ because of missing sieve sizes). Silt content was determined by pipette analysis. Grain-sizes were compared with those of different ice and water types at Matanuska Glacier described by Lawson (1979), and with those likely to be produced by different proposed mechanisms of debris-band formation (Table 1). To test for upward fining, samples were collected along one debris band at different heights above the bed.

\section{Ice fabric}

Thin sections of dirty laminated debris-band ice and surrounding englacial ice were made under the tutelage of A. J. Gow (personal communication, 1998) and examined for $c$-axis fabrics according to the methods of Langway (1958). Thin-sectioning the debris-rich ice caused local heating and possible melt-refreeze in a few instances, as identified by A. J.
Gow (personal communication, 1998). This conclusion was based on the appearance of the sections in normal light during sectioning and on appearance of acicular ice crystals radiating from silt grains in a few regions of thin sections when observed in cross-polarized light. We avoided those limited regions in our analyses. Accuracy of orientation measurement was determined by multiple analyses on samples according to the methods of Kamb (1961). Trend accuracy was $\pm 7^{\circ}$, and the plunge accuracy was $\pm 5^{\circ}$.

\section{RESULTS}

\section{Field relationships}

Matanuska Glacier almost certainly includes debris bands formed by different processes. Bands of till form in icemarginal mélanges during winter, associated with folding/ thrusting processes. Farther up-glacier, rare bands of pebble-sized, well-sorted schist chips are observed, likely related to surficial meltwater activity up-glacier.

However, the most characteristic class of Matanuska Glacier debris bands is different from these cases and forms a single, easily recognizable population; further discussion here focuses only on this distinct population. The common debris bands of Matanuska Glacier are laminated, sediment-rich structures observed at the surface within and down-glacier of overdeepened basins near the ice margin (Lawson and others, 1998; Evenson and others, 1999). These basins are associated with high water pressures due to adverse bed slopes that supercool rising basal waters (Alley and others, 1998).

Debris bands are visible only in the ablation zone and only within a few kilometers of the terminal ice margin. The absence of debris bands at the surface further up-glacier in the ablation zone suggests either the conditions for their formation may not be present up-glacier, or that favorable conditions exist but the bands do not penetrate to the ice surface. Limited ground-penetrating radar records from an upglacier location, which lacks debris-bands at the surface, reveal a few linear diffractors below the surface (D. E. Lawson, unpublished data). The diffractors are interpreted to represent debris bands that fail to reach the glacier's surface. However, our observations focus on debris bands that are exposed or are forming near the present ice margin.

The visible debris bands typically extend laterally for hundreds of meters (Fig. 1). Some strike generally north-south approximately perpendicular to ice flow, others east-west or in other orientations. Visible debris bands commonly are vertical or dip steeply up-glacier, although down-glacier and even nearly horizontal dips are observed. Dip measurements were made where debris bands were cross-cut by crevasses. Some debris bands split (Fig. 2), or split and rejoin to isolate "lozenges" of englacial ice. Some debris bands can be traced downward into the stratified basal ice (Lawson, 1979; cf. Hubbard and Sharp, 1995), but none have been observed to terminate downward above the basal ice. In at least one case, the basal ice has been offset a few centimeters at its contact with a debris band (Fig. 3), but larger offsets have not been observed.

The sediment in Matanuska Glacier debris bands is visibly concentrated in a centrally located seam (Figs 3 and 4a) or in several subparallel laminae (Fig. 4b). Commonly, the sediment-rich zones occur between subparallel clear, clean ice layers a few centimeters thick that are in contact with and cross-cut stratigraphic or other features in the bubbly, generally clean englacial ice (Fig. 4). Estimated sediment content 


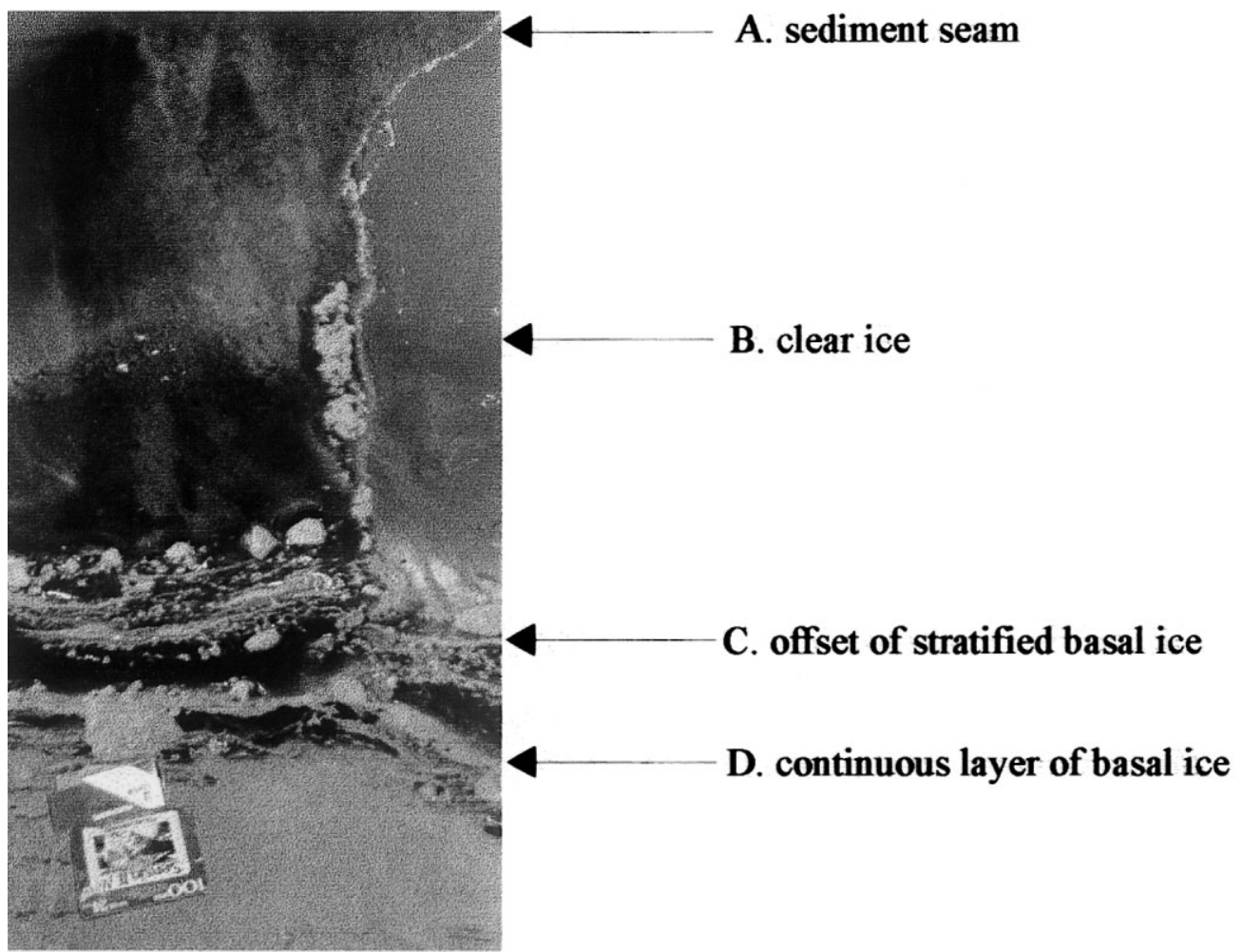

\begin{abstract}
Fig. 3. Debris band as seen inside an ice cave, looking in the down-glacier direction. Film box (bottom) for scale. Arrow A points to the central seam of sediment, which continues in the third dimension, angling off toward the left side of the photograph. Arrow B points to the clear, coarse-grained ice adjacent to the debris band. Arrow $C$ points to the offset of the top layer of the stratified basal ice. Sense of motion would be a reverse thrust. Arrow $D$ points to a continuous layer within the stratified basal ice, indicating debris-band formation took place after the top layer was accreted, but before this layer was accreted.
\end{abstract}

within debris-rich laminae is approximately $20-50 \%$ by weight. However, that value varies widely, as nearly ice-free debris has been observed in at least one debris band. Sediment released from the debris laminae by ablation forms sediment flows on the ice surface (e.g. Lawson, 1982). The sediment flows in turn cause the debris bands to appear much wider than they really are (Fig. 1). Also characteristic of these debris bands are irregular zones of mostly clear ice with low bubble concentrations that may extend from the clean debris-band layers a few centimeters into surrounding englacial ice.

Open orifices or conduits commonly occur along debris bands (Fig. 5), although most of a debris band's length along the glacier surface lacks conduits. Conduit diameters range from a few centimeters to a few tens of centimeters. Several conduits typically occur in proximity to one another along a debris band. Conduits characteristically are lined by annuli of platy ice crystals. The conduits resemble Holmlund's (1988) "fossil moulin" and Stenborg's (1968) "crystal quirke". Away from the immediate vicinity of conduits, crystals in debris-band ice typically are elongated normal to the band, consistent with inward growth from the sides. A debris band has also been observed in contact with a large $(\sim 1 \mathrm{~m}$ diameter) englacial conduit. Debris extended into the conduit from the band.

Discharge of turbid waters onto the surface of the glacier through debris-band conduits is often observed, typically within $200 \mathrm{~m}$ or so of the glacier terminus where ice thicknesses are $<100 \mathrm{~m}$. For example, in one instance a series of small (few $\mathrm{cm}$ diameter) orifices arrayed in a line a few meters long and transverse to ice flow discharged onto the surface through ice approximately $30 \mathrm{~m}$ thick. In another instance, a similar discharge through ice approximately 10-15 m thick occurred along a line roughly $30 \mathrm{~m}$ long and parallel to ice flow. One exceptional discharge of turbid water during peak summertime water flow from the glacier occurred into a supraglacial lake at the foot of an icefall about $500 \mathrm{~m}$ from the terminus, where the ice was about $100 \mathrm{~m}$ thick. Such turbid discharges onto the glacier surface typically occur in summer; however, clear discharges have been observed less frequently in winter following extensive aufeis growth in the proglacial region, which would have tended to block free drainage of ground-water.

In some cases, we have observed opening of basally connected crevasses and discharge of turbid waters leading to debris-band formation. During periods of high subglacial water pressures, as inferred from ice-velocity and waterdischarge data and discharges of turbid waters onto the ice surface (Ensminger and others, 1999a), fieldworkers in and near the ice-marginal overdeepened basin have heard and felt long-lasting (seconds or more), ringing (non-impulsive) "ice quakes", which suggest crevassing of the glacier (Blankenship and others, 1987). New crevasses opened during such periods, and some but not all of these crevasses connected with the basal water system as evidenced by the upwelling of silt-laden waters and growth of silt-laden frazil ice (Fig. 6). These basally connected crevasses typically reach the surface only where the ice is thinnest and the surface lowest, continuing laterally but failing to reach the surface in thicker ice (Fig. 6). Newly formed crevasses often cross-cut older ones, suggesting multiple generations of formation under changing stress states (e.g. Whillans and others, 2001).

\section{Tritium concentrations}

The four laminated debris bands sampled during 1996 are significantly enriched in ${ }^{3} \mathrm{H}$ compared with englacial ice 
a

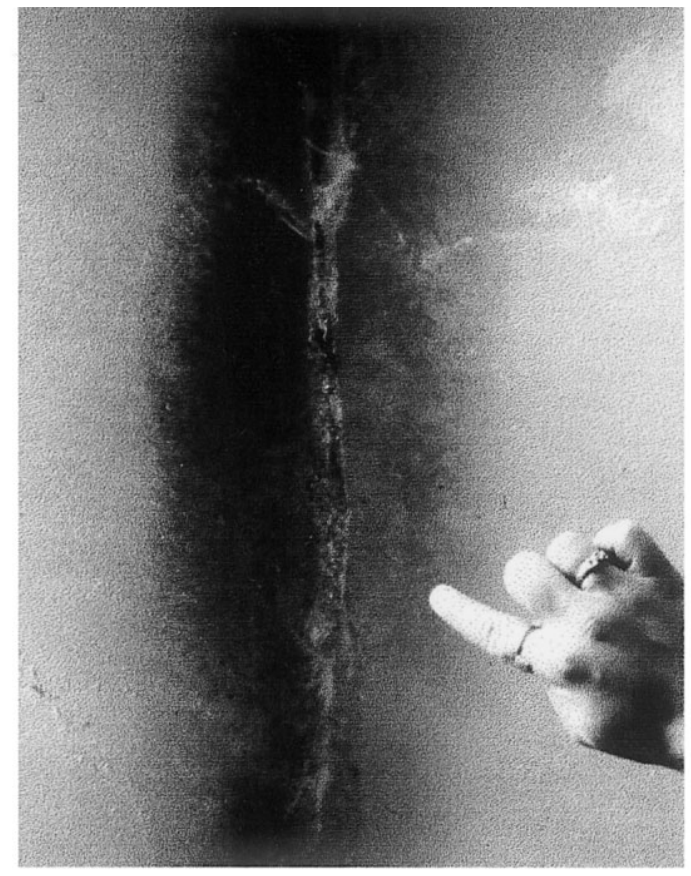

b

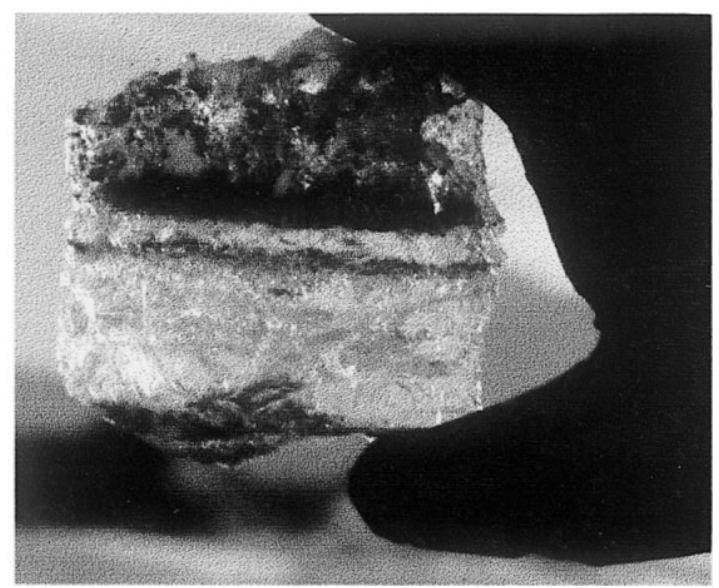

Fig. 4. Layered structure of debris bands. (a) Centrally located seam of sediment is surrounded on either side by clear, coarse-grained ice that is adjacent to coarse-grained bubbly englacial ice. The contact between the clear and bubbly ice is diffuse. (b) Hand sample chipped away from a debris band having multiple laminations. Gloved hand for scale. The ice between sediment laminae is typically very clear (bottom), though the sediment is not always restricted to the laminations (top). Sediment grain-size consists of fine sand and silt.

(7.0 TU vs $<1 \mathrm{TU}$, different with $>98 \%$ confidence based on $t$ tests; Table 2). Isotopic fractionation during freezing is small compared with these differences and can be ignored (Strasser and others, 1996). The high ${ }^{3} \mathrm{H}$ concentrations indicate presence of bomb-produced ${ }^{3} \mathrm{H}$, similar to post-1952 precipitation. Debris-band ${ }^{3} \mathrm{H}$ concentrations are similar to those of basal meltwater, and ice grown from that meltwater, but distinct from the englacial ice of which most of the glacier is composed (Table 2; see also Strasser and others, 1996). However, the laminated debris band sampled in detail during 1997 had ${ }^{3} \mathrm{H}$ concentrations not much higher than those of englacial ice (1-3 TU vs $\sim 1 \mathrm{TU}$ for englacial ice; Fig. 7). Formation of this band probably occurred before 1952, and probably $>3 \mathrm{~km}$ up-glacier based on extrapolation of measured ice velocities near the margin (Ensminger and others, 1999a; cf. Titus and others, 1999).

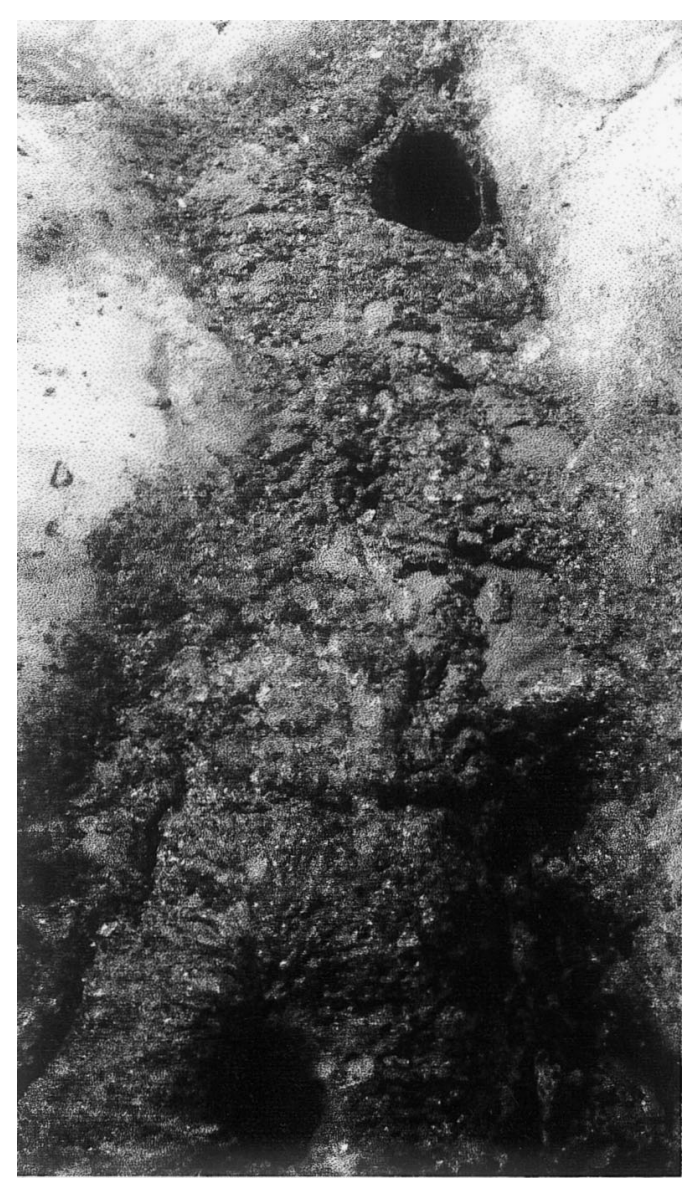

Fig. 5. Trwo open conduits found adjacent to one another in a debris band. The conduit near the top of the photograph is $10 \mathrm{~cm}$ in diameter. Both conduits were open to a depth of approximately $2 \mathrm{~m}$ from the ice surface, at which point they appeared to be closed. The conduits may indicate crevasse closure or flow of supercooled water into fractures, with eventual closure by ice growth and ice flow.

\section{Stable-isotopic ratios}

Stable-isotopic data are listed in Table 3. Previous work at Matanuska Glacier (Lawson and Kulla, 1978; Strasser and others, 1996; Lawson and others, 1998; Titus and others, 1999) has shown that much of the subglacial discharge is derived from melting of englacial ice with little isotopic fractionation. Frazil, anchor and stratified basal ice grow in front of and beneath the glacier by freezing a very small fraction of the voluminous subglacial discharge during supercooling conditions in an open hydrologic system

Table 2. Maximum, minimum, and ${ }^{3} \mathrm{H}$ values (TU) of dirty ice from bulk debris-band samples and their surrounding englacial ice compared with different ice and water types at Matanuska Glacier

\begin{tabular}{lrrrc}
\hline Ice or water type & ${ }^{3} H_{\max T U}{ }^{3} H_{\min T U}$ & ${ }^{3} H_{\text {ave TU }}{ }^{3} H_{\text {stdev TU }}$ \\
\hline Dirty laminated debris-band ice & 10.2 & 4.6 & 7.0 & 2.5 \\
Englacial ice $^{\text {Stratified basal ice }}{ }^{1}$ & 1.2 & -0.1 & 0.7 & 0.5 \\
$\quad$ Profile 95-la & 91.5 & 13.3 & 38.5 & 18.6 \\
$\quad$ Profile 95-lc & 35.7 & -0.9 & 11.3 & 8.7 \\
Subglacial discharge $^{1}$ & 8.7 & 7.2 & 7.8 & 0.7 \\
Frazil and anchor ice $^{1}$ & 8.9 & 7.4 & 7.9 & 0.9 \\
\end{tabular}

${ }^{1}$ Strasser and others (1996). 

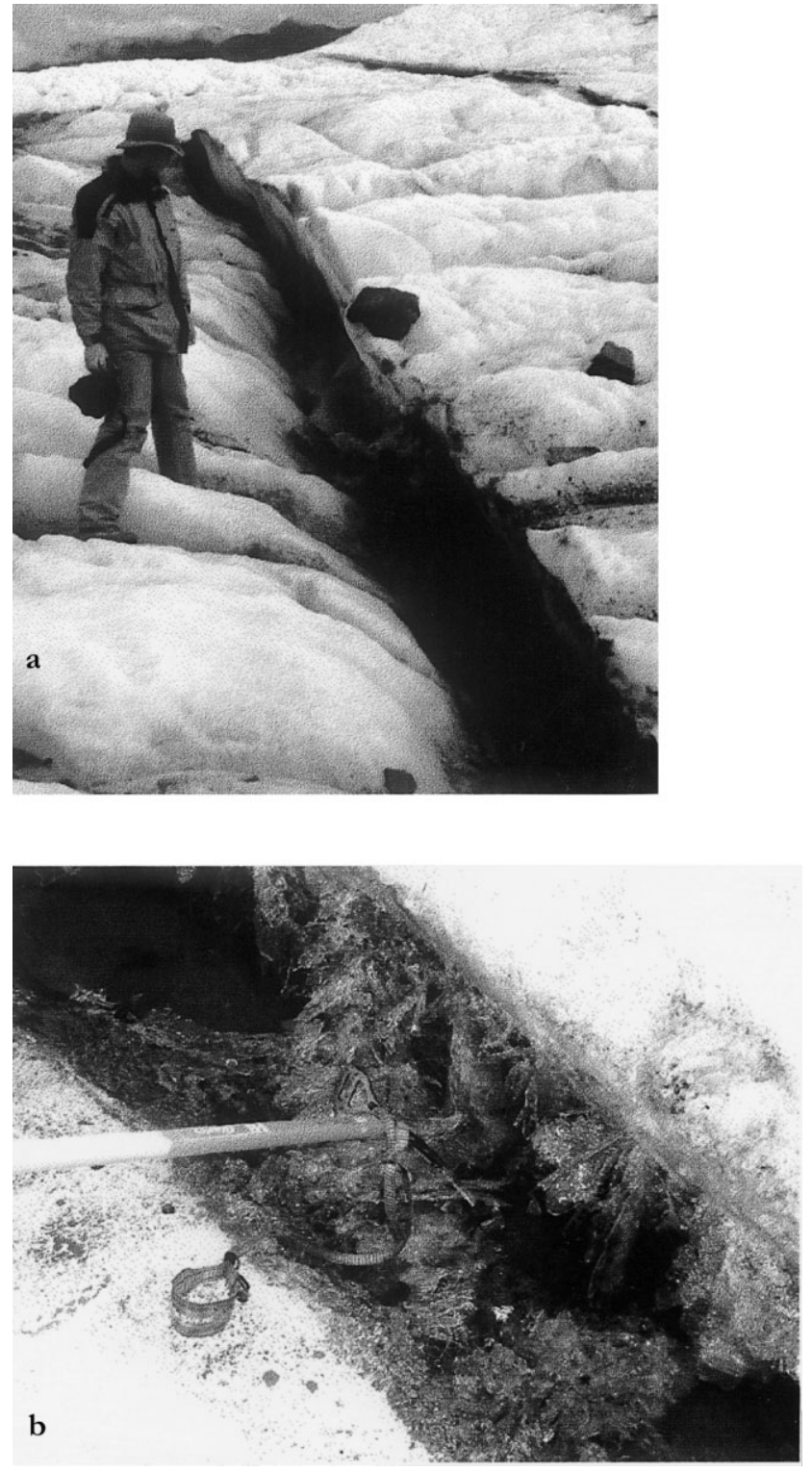

Fig. 6. Crevasses connecting to the basal drainage system upwell with debris-rich water. (a) Basal crevasse exposed at the surface along a $10 \mathrm{~m}$ segment of its length. Crevasse is "blind" in upper part of the photograph. (b) Ice growth inward from the walls of the crevasse exposed during the diurnal low-flow period. Mountaineering axe-head $30 \mathrm{~cm}$ for scale.

(Titus and others, 1999). Taken together, frazil, anchor and stratified basal ice are isotopically heavier than the ice in dirty laminae of debris bands with $>99 \%$ confidence based

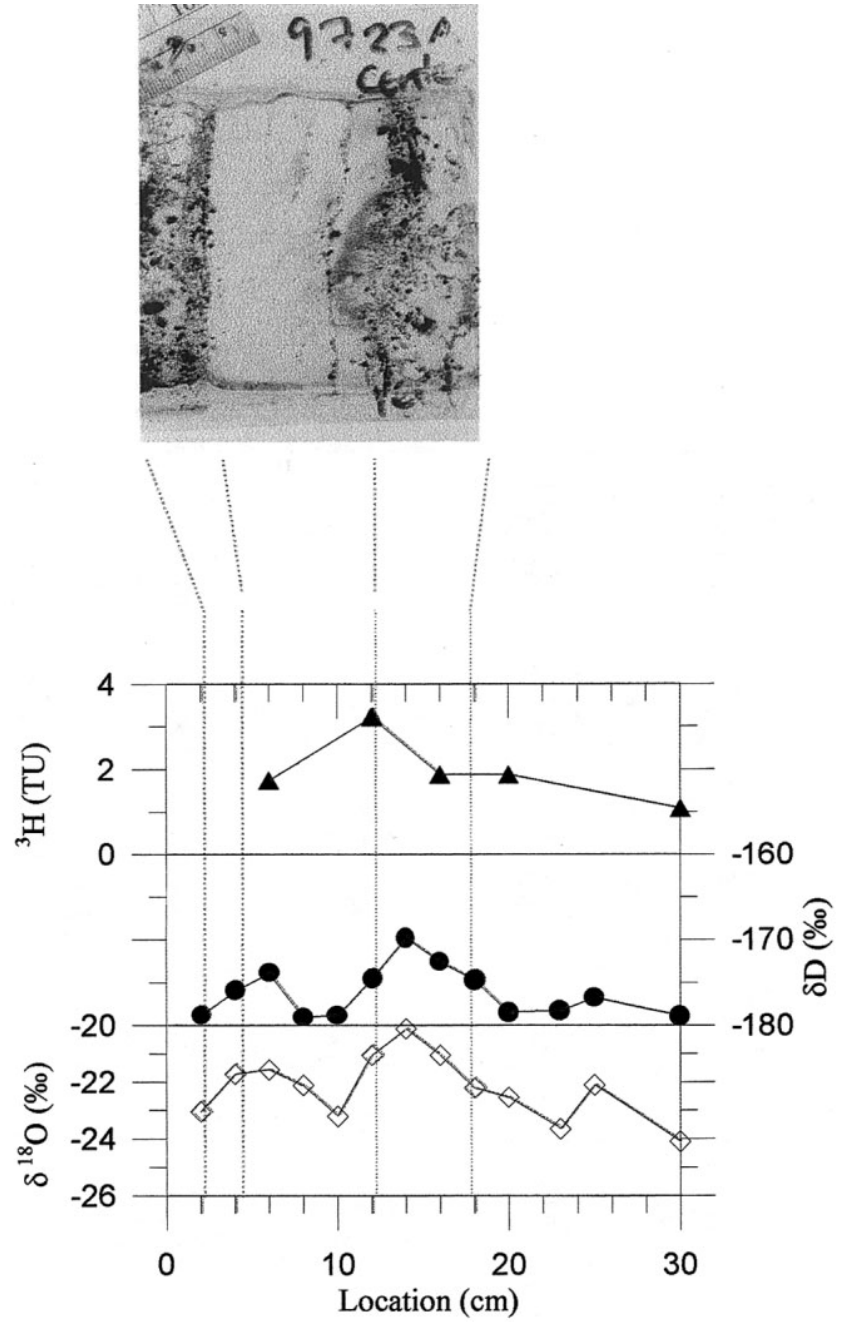

Fig. 7. Isotopic values of a transect across a laminated debris band $(0-18 \mathrm{~cm})$, clear englacial ice $(18-27 \mathrm{~cm})$ and bubbly englacial ice $(27-30 \mathrm{~cm})$. A thin section of the debris-band ice is shown above in normal light. Note that the clean ice in the debris band $(8-12 \mathrm{~cm})$ has lighter stable-isotopic values than the debris-rich debris-band ice $(4-6$ and $12-18 \mathrm{~cm}) .{ }^{3} \mathrm{H}$ values are not significantly above background levels.

on a $t$ test of their oxygen- and deuterium-isotopic ratios. The ice in dirty laminae is heavier than the ice in clear laminae and irregular regions of clear, bubble-free ice adjacent to the debris bands, which in turn are slightly heavier than englacial ice. The difference between isotopic ratios of ice in the dirty laminae and the englacial ice is significant with $>95 \%$ confidence based on a $t$ test.

Table 3. Maximum, minimum, and average $\delta^{18} O$ and $\delta D$ values (per mil) for dirty laminated debris-band ice, clear laminated debrisband ice and their surrounding englacial ice compared with different ice and water types at Matanuska Glacier

\begin{tabular}{|c|c|c|c|c|c|c|c|c|c|}
\hline Ice or water type & $\mathcal{N}$ & $\delta^{18} O_{\max }$ & $\delta^{18} O_{\min }$ & $\delta^{18} O_{\text {ave }}$ & $\delta^{18} O_{\text {stdev }}$ & $\delta^{18} O_{\max }$ & $\delta^{18} O_{\min }$ & $\delta^{18} O_{\text {ave }}$ & $\delta^{18} O_{\text {stdev }}$ \\
\hline Dirty laminated debris-band ice & 23 & -20.1 & -24.5 & -22.4 & 1.0 & -159.5 & -178.2 & -170.8 & 6.0 \\
\hline Clear laminated debris-band ice & 6 & -21.8 & -24.1 & -22.8 & 0.9 & -173.6 & -180.0 & -176.8 & 2.6 \\
\hline Englacial ice & 19 & -21.8 & -25.8 & -24.0 & 1.3 & -159.0 & -189.0 & -177.2 & 10.4 \\
\hline Clear ice adjacent to laminae & 17 & -22.9 & -24.9 & -23.7 & 0.7 & -163.8 & -195.1 & -176.8 & 7.7 \\
\hline Stratified basal ice ${ }^{1}$ & 158 & -19.6 & -23.3 & -21.0 & 0.6 & -149.0 & -178.0 & -163.8 & 4.7 \\
\hline Frazil and anchor ice ${ }^{2}$ & 10 & -20.7 & -23.5 & -21.4 & 0.8 & -160.0 & -179.0 & -165.3 & 5.4 \\
\hline Precipitation $^{2}$ & 24 & -11.3 & -28.4 & -20.9 & 5.1 & -101.0 & -223.0 & -165.5 & 35.4 \\
\hline
\end{tabular}

${ }^{1}$ Strasser and others (1996).

${ }^{2}$ Lawson and others (1998). 


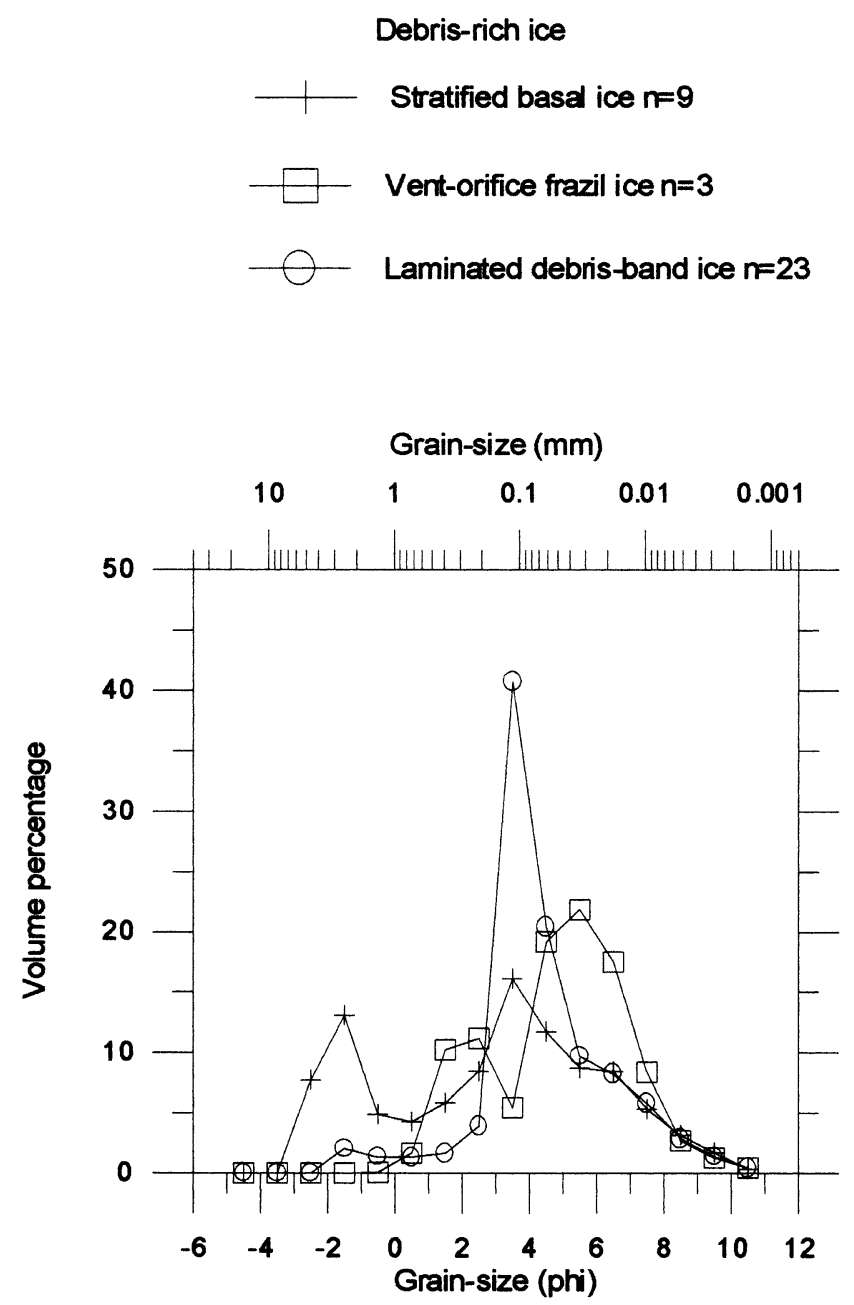

Fig. 8. Sediment grain-size distributions for vent frazil ice, stratified basal ice and debris-band ice. The sediment in debris-band ice is extremely well-sorted fine sand. Grain-size distribution in basal-and frazil-ice types is not unimodal and contains greater volume percentages of coarse sand and pebbles.

\section{Sediment grain-size}

Sediment found within the debris-band ice had an average grain-size of $4.8 \phi$ (coarse silt) and was fairly well sorted ( $s=2.7 \phi$; Fig. 8). This closely resembles the suspended load in the subglacial streams discharging from Matanuska Glacier (Lawson, 1993), and is not statistically distinguishable from the fine-fraction of the stratified basal ice. The grainsize distribution of the sediment in the debris-band ice does not resemble the angular supraglacial debris described by Lawson (1979) ( $-3 \phi$ to $1 \phi)$, and resembles only the fine fraction of debris in subglacial sediments (sand to silt; Lawson, 1979). The debris bands entirely lack a coarse fraction and striated stones observed in subglacial and proglacial streams and tills.

\section{Ice fabric}

Figure 9 shows the orientation fabrics of the englacial ice on either side of a low- ${ }^{3} \mathrm{H}$ debris band and of the debris-free ice in the debris band. Insufficient orientation data were obtained from debris-rich ice for statistical analysis, due to melting and refreezing during the thin-sectioning process. There is little difference between texture and fabric of the debris band and surrounding englacial ice.

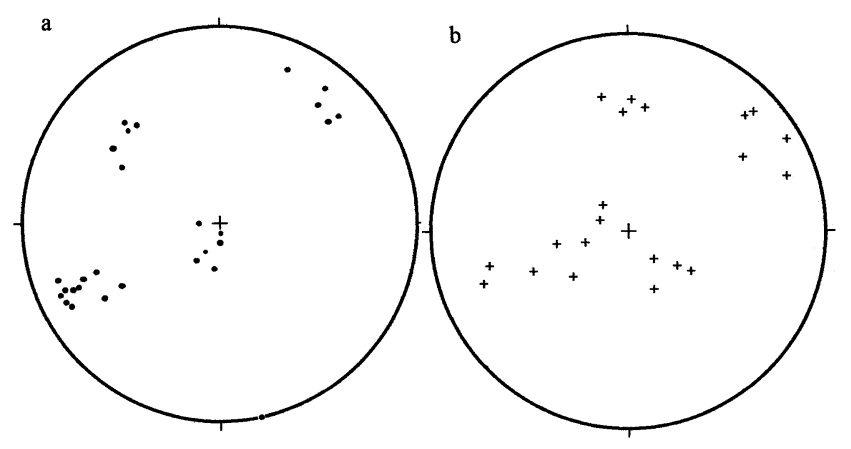

Fig. 9. c-axis orientations from horizontal thin sections of (a) 25 englacial ice crystals from one sample, and (b) 21 clear debris-band ice crystals from one sample. In the field, samples were not oriented at the time of collection. Therefore, the Schmidt equal-area lower-hemisphere stereographic plots can be freely rotated. A total of 91 orientations were measured in the englacial ice, and 75 were measured in clear debris-band ice taken from multiple samples. Both ice types show four weak fabric maxima. Accuracy of measurements was $\pm 7^{\circ}$ for the trend and $\pm 5^{\circ}$ for the plunge.

\section{SYNTHESIS AND DISGUSSION}

\section{Debris-band origin}

As noted above, debris bands are undoubtedly polygenetic across glaciers and even at Matanuska Glacier. However, our data provide high confidence that the common debris bands of Matanuska Glacier were formed by injection of turbid waters into basal crevasses.

The Matanuska Glacier debris bands lack coarse clasts related to shearing or folding of basal debris into the ice, or squeezing/creep of till into large basal crevasses. Instead, the size distribution of the debris is similar to that of the suspended load of subglacial discharge and of ice grown from supercooling of that subglacial discharge.

The debris-band ice is isotopically distinct from adjacent englacial ice, whereas materials buried supraglacially or sheared or folded in would probably occur in englacial ice. The debris-band ice does show isotopic similarities to ice grown from proglacial and subglacial waters. ${ }^{3} \mathrm{H}$ concentrations are elevated in most debris-band ice tested. Such levels are distinct from englacial ice but are instead similar to subglacial waters and to ice known to have grown from those subglacial waters. Stable-isotopic ratios of the debrisband ice differ significantly from those of englacial ice and basal meltwaters, but are consistent with origin by freezing from basal meltwaters, as discussed below. Additionally, the lack of air bubbles in debris-band ice would suggest a possible accretionary origin for it (Gow and others, 1979).

Limited data from one debris band show $c$-axis fabrics similar to those in adjacent englacial ice. Anomalous $c$-axis fabrics associated with strong localized shearing or folding (e.g. Gow and Williamson, 1976; Budd and Jacka, 1989; Alley, 1992; Paterson, 1994) are absent. However, this debris band proved to have low ${ }^{3} \mathrm{H}$ levels, suggesting that it may have formed before 1952 well up-glacier, so we cannot exclude the possibility that a fabric associated with localized shearing has been removed by subsequent recrystallization under "normal" glacier flow to cumulative strains of order $10 \%$ or more (Budd and Jacka, 1989). 
Finally, field observations show debris-band formation through ice growth on new crevasse walls into upwelling turbid-water discharges reaching the glacier surface. With this weight of evidence, we argue that the common Matanuska Glacier debris bands were formed by injection of turbid basal meltwater into basal crevasses.

\section{Active processes}

Although the broad outline of the formation mechanism of Matanuska Glacier debris bands thus is clear, many of the details are not. However, available data provide some insight and suggest further hypotheses.

Field observations show that turbid basal meltwaters are injected into narrow cracks or fractures, which we call basal crevasses although there is no evidence that they typically open wider than millimeters. These basal crevasses reach the upper ice surface in some places, but probably more typically terminate upwards below the surface. Upward water flow occurs both in widespread sheets and occasionally through concentrated vents, producing ice-crystal growth into the spaces.

Thermodynamic considerations (Alley and others, 1998) as well as field observations indicate that the rise in the pressuremelting temperature in response to falling pressure on upwelling water can cause supercooling and ice growth. Thus, ice growth is expected during water injection and throughflow.

In addition, earlier work on temperate glaciers suggests that some in situ freezing may occur in waters trapped in crevasses following injection. Harrison (1972) noted that boreholes in temperate glaciers typically close by freezing, and discussed contributions to this freezing from the effects of impurities, dissolved gases and stress state. Raymond (1976) further noted that stresses associated with overpressured bubbles in ice flowing towards the surface in the ablation zone will lower the melting point in that ice.

We thus expect that many processes contribute to debrisband formation. Water injected into a basal crevasse may escape upward to the surface, laterally into englacial drainage channels, or back downward in response to a subsequent fall in basal water pressure, with small amounts "soaking" adjacent ice by moving into bubbles or intergranular veins along the crevasse, and with some diffusive exchange with adjacent englacial ice. Sediment may be trapped between growing crystals, in adjacent veins or bubbles, or by asperities on the fracture surfaces. Ice may grow from supercooling of upwelling waters owing to falling pressure, or from stress relief associated with crevassing or other processes affecting nearly stagnant waters trapped in fractures following injection.

Our isotopic and sediment-grain-size data suggest that several of these processes have been active in formation of the observed debris bands of Matanuska Glacier. The debris bands commonly have high $(>2 \mathrm{TU}){ }^{3} \mathrm{H}$ concentrations, indicating freezing of waters that fell as precipitation more recently than the first large atmospheric atomic-bomb tests in 1952. The ${ }^{3} \mathrm{H}$ content of the debris bands is close to or slightly lower than expected for recent freezing of summertime basal meltwaters (2.5-8 TU, Strasser and others, 1996; Lawson and others, 1998; Titus and others, 1999), which is consistent with recent formation and with only a little diffusive or other admixture of ${ }^{3} \mathrm{H}$-free englacial ice.

The ${ }^{3} \mathrm{H}$ data also could be explained by debris-band formation soon after atmospheric atomic-bomb testing, when ${ }^{3} \mathrm{H}$ concentrations were higher, or more recently during wintertime from the relatively ${ }^{3} \mathrm{H}$-enriched ground-water
(26 TU; Strasser and others, 1996; Lawson and others, 1998), and large dilution by diffusive or other admixture of ${ }^{3} \mathrm{H}$-free englacial ice. However, these models are inconsistent with our observations that basal crevassing usually is a summertime phenomenon and occurs primarily near the glacier terminus.

The ${ }^{3} \mathrm{H}$ data thus suggest that the dirty ice of debris bands is primarily refrozen meltwater rather than englacial ice. The stable-isotopic data then suggest that this dirty ice grew both from an open hydrological system and by in situ closed-system freezing. The stable-isotopic ratios of the dirty laminae of debris bands typically are lighter than frazil, anchor and stratified basal ice types that have grown by freezing of only a small fraction of through-flowing water in an open hydrological system (Lawson and others, 1998), but are heavier than englacial ice, basal meltwater and any ice that would form by complete refreezing of basal meltwater (Souchez and Lorrain, 1991; Lawson and others, 1998). This is most easily explained if both open- and closedsystem ice are present in the debris bands.

The sediment grain-size variation with height above the bed also bears on this issue. Where samples were collected along one debris band, the average sediment grain-size at an unknown height above the bed was $4.78 \phi(n=15)$, and the average grain-size in that same debris band about $10 \mathrm{~m}$ higher was $5.58 \phi(n=5)$, indicating upward fining with about $75 \%$ confidence based on a $t$ test. Stokes'-law settling velocities for clasts of this size are on the order of $1 \mathrm{~mm} \mathrm{~s}^{-1}$. Slight upward fining on this scale is consistent with upward fluid-flow velocities slightly higher than the settling velocity but of the same order of magnitude. Faster flows would have swept the sediment out of the system before significant sorting had taken place. Water emerging from conduits at the surface typically flows much faster than this, indicating that the debris band was not formed primarily from such conduit flow. However, water standing freely in a crevasse for a few days or longer would have allowed greater sorting than observed. Accepting the measured upward fining at face value permits slow opening of basal crevasses, slow sheet-like throughflow of water, or more rapid opening and injection followed by closing in some fashion over the order of 1 day.

Taken together, these observations indicate that multiple processes contribute to debris-band formation, including open-system freezing from upwelling waters and in situ freezing from injected waters. This interpretation, while not unique, is in good accord with field observations.

Several additional hypotheses require testing with further data. The complex layered structure of many debris bands suggests multiple crevasse-opening events, with later crevassing exploiting planes of weakness left by imperfect crevasse closure from previous events. Such exploitation of a pre-existing debris band occurred along one band during the summer 2000 field season. We cannot rule out the possibility that some of the clear laminae within debris bands represent a plastic process zone formed during fracturing (Engelder and others, 1993), rather than an origin by soaking or by the injection of clean water in some other way. Debris bands may be subject to post-freezing modification, such as slight melting if weathering of silt produces ions that lower the melting point of dirty ice after stress equilibration, although the recent formation of most bands argues against large changes in this way (Ensminger, 2000). Finally, conduits that localize upwelling water flow along some crevasses may be former moulins, which may be important in nucleation or propagation of the basal crevasses. 


\section{Occurrence of basal crevassing}

Basal crevassing is increasingly understood to be a widespread phenomenon, having been observed in many glacial environments or inferred on the basis of good evidence. These environments include floating ice shelves (e.g. Jezek and others, 1985), an Antarctic ice stream (Novick and others, 1992), tidewater calving termini (e.g. Mickelson and Berkson, 1974), surging glaciers (e.g. Sharp, 1984) and an outlet glacier during a jökulhlaup (Roberts and others, 2000).

Basal crevassing is favored by high basal water pressures to offset the weight of the ice, by longitudinally extensional stresses in basal ice and by heterogeneities that serve to nucleate fractures, all of which are features of Matanuska Glacier. Ice flow over rough topography, as evidenced by ground-penetrating radar beneath Matanuska Glacier (Lawson and others, 1998), is expected to produce regions that are locally extensional as well as locally compressive. For example, Hanson (1995, and personal communication, 2000) modeled flow of Storglaciären, Sweden, and found basal values of extensional longitudinal-deviatoric stresses of $>120 \mathrm{kPa}$ in ice flowing into the upper overdeepened basin, and $>40 \mathrm{kPa}$ flowing into the lower overdeepened basin. Matanuska Glacier, with faster flow (Ensminger and others, 1999a) and rougher basal topography (Lawson and others, 1998), is likely to generate similar or larger stresses. Fountains of turbid basal water occasionally released onto the surface of Matanuska Glacier document the occurrence of high basal water pressures locally in excess of flotation. Observations of the basal zone show that the basal ice is heterogeneous (Lawson and others, 1998), providing contrasts that along with moulins could serve to nucleate fractures. Matanuska Glacier is thus a likely candidate for basal crevassing.

Field observations indicate that crevassing usually occurs without significant thrusting or strike--slip motion, so that crevasses are primarily mode-I or opening-mode cracks (Paterson, 1994), with the greatest extensional stress parallel to the bed and most typically in the direction of ice flow through the overdeepened basin. However, the fewcentimeter offset of basal ice along the debris band shown in Figure 3 indicates that mixed-mode fractures can also occur (cf. Hambrey and Müller, 1978). The splitting and rejoining of some debris bands around lozenge-shaped regions of englacial ice may also indicate some component of shear in that part of the debris band (Schulson, 1987).

Abrupt water-pressure changes associated with crevassing may be important in driving fractures through subglacial rock, and thus in facilitating erosion (Iverson, 1991). The longitudinal extension associated with flow into overdeepened basins (Hanson, 1995) would tend to localize basal crevassing, and any associated water-pressure variation and erosion, on the headwalls of overdeepened basins (Alley and others, 1999). The effects would contribute to the feedbacks identified by Hooke (1991) that serve to generate and strengthen overdeepened basins (Alley and others, 1999). Basal crevassing also may provide a mechanism by which basal and englacial waters can mix (cf. Humphrey and others, 1993; Hooke and Pohjola, 1994) and be forced into the englacial zone (Weertman, 1973; Holmlund, 1988; Lawson and Hunter, 1996).

\section{GONGLUSIONS}

The most common debris bands in the terminus region of Matanuska Glacier were formed by injection of turbid waters into basal crevasses, not by burial of supraglacial debris or thrusting of subglacial debris. The Matanuska Glacier debris bands are millimeters-to-centimeters thick, laminated features, most typically steeply dipping. The debris-band sediment is dominated by well-sorted coarse silt to very fine sand. The debris-band ice usually contains atomic-bomb ${ }^{3} \mathrm{H}$ but cross-cuts ${ }^{3} \mathrm{H}$-poor englacial ice. The stable-isotopic ratios of debris-band ice are consistent with freezing from basal waters, but are distinct from englacial ice. The $c$-axis fabrics near one debris band do not reveal evidence of active band-parallel shearing. Radar data and surface observations suggest that crevassing is common beneath the glacier, and our inferences of the stress state and basal water system are consistent with occurrence of basal crevassing.

The ice of debris bands is likely to form by some combination of in situ freezing following injection from below, and supercooling during injection and throughflow from the bed to englacial conduits or the surface. Soaking during freezing may be involved in the formation of clear laminae adjacent to sediment-laden ones, and of irregular bubble-free zones in englacial ice beyond the clear laminae. Waters may drain downward following injection, and additional waters may be injected, owing to changing pressure in the basal hydrological system and changing stress state in the glacier. More observations are required to test these hypotheses.

Basal crevassing is important in moving sediment above the basal zone of Matanuska Glacier, and thus may contribute to sediment-flow development (e.g. Lawson, 1982), reduced albedo, increased ablation of the glacier and increased erosion rates. Basal crevassing is one of several processes that might provide a "safety valve" limiting locally high basal water pressures, but basal crevassing can also contribute to rapid changes in basal water pressures that might effect bedrock fracturing and erosion.

\section{ACKNOWLEDGEMENTS}

The authors thank the U.S. Army Corps of Engineers Cold Regions Research and Engineering Laboratory (CRREL) (grant DACA89-95-K-0007) and the U.S. National Science Foundation (grant OPP-9530757) for financial support. We especially extend our thanks to W. and K. Stevenson of Glacier Park Resort, Alaska, for their logistical support and without whose help this project would not have been possible. Students of Lehigh University, Augustana College, Northwest Missouri State University and Glacier View High School, Alaska, provided field assistance. T. Gow and S. Bigl of CRREL were especially helpful with laboratory analyses, and B. Hanson graciously supplied additional unpublished results of his model runs. Reviews by M.J. Hambrey and M. R. Bennett greatly improved the manuscript.

\section{REFERENGES}

Alley, R. B. 1992. Flow-law hypotheses for ice-sheet modeling. F. Glaciol., 38(129), 245-256.

Alley, R. B., A. J. Gow, D. A. Meese, J. J. Fitzpatrick, E. D. Waddington and J. F. Bolzan. 1997a. Grain-scale processes, folding and stratigraphic dis- 
turbance in the GISP2 ice core. 7. Geophys. Res., 102 (C12), 26,819-26,830.

Alley, R. B., K. M. Cuffey, E. B. Evenson, J. C. Strasser, D. E. Lawson and G. J. Larson. 1997b. How glaciers entrain and transport basal sediment: physical constraints. Quat. Sci. Rev., 16(9), 1017-1038.

Alley, R. B., D. E. Lawson, E. B. Evenson, J. C. Strasser and G. J. Larson, 1998. Glaciohydraulic supercooling: a freeze-on mechanism to create stratified, debris-rich basal ice. II. Theory. F. Glaciol., 44(148), 563-569.

Alley, R. B., J. C. Strasser, D. E. Lawson, E. B. Evenson and G. J. Larson. 1999. Some glaciological and geological implications of basal-ice accretion in an overdeepening. In Mickelson, D. M. and J.W. Attig, eds. Glacial processes: past and present. Boulder, CO, Geological Society of America, 1-9. (Special Paper 337.)

Bennett, M. R., D. Huddart and R. I. Waller. 2000. Glaciofluvial crevasse and conduit fills as indicators of supraglacial dewatering during a surge, Skeiðarárjökull, Iceland. F. Glaciol., 46 (152), 25-34.

Bishop, B. C. 1957. Shear moraines in the Thule area, northwest Greenland. SIPRE Res. Rep. 17.

Blankenship, D. D., S. Anandakrishnan, J. L. Kempf and C. R. Bentley. 1987. Microearthquakes under and alongside Ice Stream B, Antarctica, detected by a new passive seismic array. Ann. Glaciol., 9, 30-34.

Boulton, G. S. 1970. On the origin and transport of englacial debris in Svalbard glaciers. F. Glaciol., 9(56), 213-229.

Budd, W. F. and T. H. Jacka. 1989. A review of ice rheology for ice sheet modelling. Cold Reg. Sci. Technol., 16(2), 107-144.

Clarke, G. K. C. and E.W. Blake. 1991. Geometric and thermal evolution of a surge-type glacier in its quiescent state: Trapridge Glacier, Yukon Territory, Canada, 1969-89. F. Glaciol., 37(125), 158-169.

Ehlers, J. 1981. Some aspects of glacial erosion and deposition in north Germany. Ann. Glaciol., 2, 143-146.

Engelder, T., M. P. Fischer and M. R. Gross. 1993. Geological aspects of fracture mechanics. Boulder, CO, Geological Society of America. (Short Course Notes.)

Ensminger, S. L. 2000. Basal processes at Matanuska Glacier, Alaska and a model of basal freeze-on beneath the Laurentide ice sheet. (Ph.D. thesis, Lehigh University, Bethlehem, PA.)

Ensminger, S. L., E. B. Evenson, R. B. Alley, G. J. Larson, D. E. Lawson and J. C. Strasser. 1999a. Example of the dependence of ice motion on subglacial drainage system evolution: Matanuska Glacier, Alaska, United States. In Mickelson, D. M. and J.W. Attig, eds. Glacial processes: past and present. Boulder, CO, Geological Society of America, 11-22. (Special Paper 337.)

Ensminger, S. L., E. B. Evenson, G. J. Larson, D. E. Lawson, R. B. Alley and J. C. Strasser. 1999b. Preliminary study of laminated, silt-rich debris bands: Matanuska Glacier, Alaska, U.S.A. Ann. Glaciol., 28, 261-266.

Evenson, E. B. and J. M. Clinch. 1987. Debris transport mechanisms at active alpine glacier margins: Alaska case studies. In Kujansuu, R. and M. Saarnisto, eds. INQUA Till Symposium, Finland 1985. Espoo, Geological Society of Finland, 111-136. (Geol. Surv. Finl. Spec. Pap 3.)

Evenson, E. B. and 6 others. 1999. Field evidence for the recognition of glaciohydraulic supercooling. In Mickelson, D. M. and J.W. Attig, eds. Glacial processes: past and present. Boulder, CO, Geological Society of America, 23-35. (Special Paper 337.)

Folk, R. L. 1974. Petrology of sedimentary rocks. Second edition. Austin, TX, Hemphill Press.

Gat, J. R. 1980. The isotopes of hydrogen and oxygen in precipitation. In Fritz, P. and J. C. Fontes, eds. Handbook of environmental isotope geochemistry. Amsterdam, Elsevier, 21-47.

Glasser, N. F., M. J. Hambrey, K. R. Crawford, M. R. Bennett and D. Huddart. 1998. The structural glaciology of Kongsvegen, Svalbard, and its role in landform genesis. F. Glaciol., 44(146), 136-148. (Erratum: 46(154), 2000, p. 538.

Goldthwait, R. P. 1951. Development of end moraines in east-central Baffin Island. F. Geol., 59 (6), 567-577.

Gow, A. J. and T. Williamson. 1976. Rheological implications of the internal structure and crystal fabrics of the West Antarctic ice sheet as revealed by deep core drilling at Byrd Station. Geol. Soc. Am. Bull., 87(12), 1665-1677.

Gow, A. J., S. Epstein and W. Sheehy. 1979. On the origin of stratified debris in ice cores from the bottom of the Antarctic ice sheet. F. Glaciol., 23(89), $185-192$

Grove, J. M. 1960. A study of Veslgjuv-breen. In Lewis, W.V., ed. Norwegian cirque glaciers. London, Royal Geographical Society, 69-82. (R.G.S. Research Series 4.

Gustavson, T. C. and J. C. Boothroyd. 1987. A depositional model for outwash, sediment sources, and hydrologic characteristics, Malaspina Glacier, Alaska: a modern analog of the southeastern margin of the Laurentide ice sheet. Geol. Soc. Am. Bull., 99(2), 187-200.

Hambrey, M. J. and F. Müller. 1978. Structures and ice deformation in the White Glacier, Axel Heiberg Island, Northwest Territories, Canada. f. Glaciol., 20(82), 41-66.

Hambrey, M. J., J.A. Dowdeswell, T. Murray and P. R. Porter. 1996. Thrusting and debris entrainment in a surging glacier: Bakaninbreen, Svalbard. Ann. Glaciol., 22, 241-248.

Hambrey, M. J., M. R. Bennett, J. A. Dowdeswell, N. F. Glasser and D. Huddart. 1999. Debris entrainment and transfer in polythermal valley glaciers. F. Glaciol., 45(149), 69-86.

Hanson, B. 1995. A fully three-dimensional finite-element model applied to velocities on Storglaciären, Sweden. F. Glaciol., 41(137), 91-102.

Harrison, W. D. 1972. Temperature of a temperate glacier. F. Glaciol., 11(61), $15-29$.

Holmlund, P. 1988. Internal geometry and evolution of moulins, Storglaciären, Sweden. F. Glaciol., 34(117), 242-248.

Hooke, R. LeB. 1973. Structure and flow in the margin of the Barnes Ice Cap, Baffin Island, N.W.T., Canada. F. Glaciol., 12(66), 423-438.

Hooke, R. LeB. 1991. Positive feedbacks associated with erosion of glacial cirques and overdeepenings. Geol. Soc. Am. Bull., 103(8), 1104-1108.

Hooke, R. LeB. and V. A. Pohjola. 1994. Hydrology of a segment of a glacier situated in an overdeepening, Storglaciären, Sweden. F. Glaciol., 40(134), $140-148$.

Hubbard, B. and M. Sharp. 1995. Basal ice facies and their formation in the western Alps. Arct. Alp. Res., 27 (4), 301-310.

Hudleston, P. J. and R. LeB. Hooke. 1980. Cumulative deformation in the Barnes Ice Cap and implications for the development of foliation. Tectonophysics, $\mathbf{6 6}(1-3), 127-146$.

Humphrey, N., B. Kamb, M. Fahnestock and H. Engelhardt. 1993. Characteristics of the bed of the lower Columbia Glacier, Alaska. F. Geophys. Res., $98(\mathrm{Bl}), 837-846$.

Iverson, N. R. 1991. Potential effects of subglacial water-pressure fluctuations on quarrying. F. Glaciol., 37 (125), 27-36.

Jezek, K. C., R. B. Alley and R. H. Thomas. 1985. Rheology of glacier ice. Science, 227(4692), 1335-1337.

Kamb, W. B. 1961. The glide direction in ice. F. Glaciol., 3(30), 1097-1106.

Koteff, C. 1974. The morphologic sequence concept and deglaciation of southern New England. In Coates, D. R., ed. Glacial geomorphology. Binghamton, NY, State University of New York, 121-144.

Koteff, C. and F. Pessl, Jr. 1981. Systematic ice retreat in New England. U.S. Geol. Surv. Prof. Pap. 1179.

Langway, C. C., Jr. 1958. Ice fabrics and the universal stage. SIPRE Tech. Rep. 62.

Lawson, D.E. 1979. Sedimentological analysis of the western terminus region of the Matanuska Glacier, Alaska. CRREL Rep. 79-9.

Lawson, D. E. 1982. Mobilization, movement and deposition of active subaerial sediment flows, Matanuska Glacier, Alaska. F. Geol., 90(3), 279-300.

Lawson, D. E. 1993. Glaciohydrologic and glaciohydraulic effects on runoff and sediment yield in glacierized basins. CRREL Monogr. 93-02.

Lawson, D. E. and L. E. Hunter. 1996. Glaciologic response to rapid fjord infilling during the marine to terrestrial transition, Muir Glacier, Glacier Bay, Alaska. [Abstract.] Geol. Soc. Am. Abstr. Programs, 28(7), 56.

Lawson, D. E. and J. B. Kulla. 1978. An oxygen isotope investigation of the origin of the basal zone of the Matanuska Glacier, Alaska. F. Geol., 86 (6), 673-685.

Lawson, D. E., J. C. Strasser, E. B. Evenson, R. B. Alley, G. J. Larson and S. A. Arcone. 1998. Glaciohydraulic supercooling: a freeze-on mechanism to create stratified, debris-rich basal ice. I. Field evidence. F. Glaciol., 44(148), 547-562.

Leventhal, J. S. and W. F. Libby. 1970. Tritium fallout in the Pacific United States. 7. Geophys. Res., 75(36), 7628-7633.

Libby, W. F. 1955. Tritium in nature. F.Wash. Acad. Sci., 45(10), 301-314.

Mickelson, D. M. and J. M. Berkson. 1974. Till ridges presently forming above and below sea level in Wachusett Inlet, Glacier Bay, Alaska. Geogr. Ann., 56A (1-2), 111-119.

Moran, S. R. 1971. Glaciotectonic structures in drift. In Goldthwait, R.P., ed. Till: a symposium. Columbus, $\mathrm{OH}$, Ohio State University Press, 127-148.

Mulholland, J.W. 1982. Glacial stagnation-zone retreat in New England: bedrock control. Geology, 10(11), 567-571.

Novick, A. N., C. R. Bentley and N. Lord. 1992. Variations in the amplitude of radar returns from the bottom of Ice Stream B, Antarctica. [Abstract.] Eos, 73 (43), Supplement, 181.

Paterson, W. S. B. 1994. The physics of glaciers. Third edition. Oxford, etc., Elsevier.

Raymond, C. F. 1976. Some thermal effects of bubbles in temperate glacier ice. F. Glaciol., 16 (74), 159-171.

Roberts, M. J., A. J. Russell, F. S. Tweed and Ó. Knudsen. 2000. Correspondence. Rapid sediment entrainment and englacial deposition during jökulhlaups. F. Glaciol., 46(153), 349-351.

Schulson, E. M. 1987. The fracture of ice $\mathrm{I}_{\mathrm{h}}$. F. Phys. (Paris), 48, Colloq. Cl, 207-218. (Supplément au 3.)

Sharp, M. 1984. Annual moraine ridges at Skálafellsjökull, south-east Iceland. 7. Glaciol., 30(104), 82-93.

Sharp, M. 1985. "Crevasse-fill" ridges - a landform type characteristic of surging glaciers? Geogr. Ann., 67A (3-4), 213-220. 
Souchez, R. A. and R. D. Lorrain. 1991. Ice composition and glacier dynamics. New York, etc., Springer-Verlag. (Springer Series in Physical Environment 8.)

Stenborg, T. 1968. Glacier drainage connected with ice structures. Geogr. Ann., 50A(1), 25-53.

Stewart, D. P. and P. MacClintock. 1971. Ablation till in northeastern Vermont. In Goldthwait, R. P., ed. Till: a symposium. Columbus, $\mathrm{OH}$, Ohio State University Press, 106-114.

Strasser, J. C., D. E. Lawson, G. J. Larson, E. B. Evenson and R. B. Alley. 1996. Preliminary results of tritium analyses in basal ice, Matanuska Glacier, Alaska, U.S.A.: evidence for subglacial ice accretion. Ann. Glaciol., 22, 126-133.

Sugden, D. E. and B. S. John. 1976. Glaciers and landscape; a geomorphological approach. London, Edward Arnold.

Titus, D. D., G. J. Larson, J. C. Strasser, D. E. Lawson, E. B. Evenson and R. B.
Alley. 1999. Isotopic composition of vent discharge from the Matanuska Glacier, Alaska: implications for the origin of basal ice. In Mickelson, D. M. and J.W. Attig, eds. Glacial processes: past and present. Boulder, CO, Geological Society of America, 37-44. (Special Paper 337.)

Weertman, J. 1961. Mechanism for the formation of inner moraines found near the edge of cold ice caps and ice sheets. F. Glaciol., 3(30), 965-978.

Weertman, J. 1973. Can a water-filled crevasse reach the bottom surface of a glacier? International Association of Scientific Hydrology Publication 95 (Symposium at Cambridge 1969-Hydrology of Glaciers), 139-145.

Whillans, I. M., C. R. Bentley and C. J. van der Veen. 2001. Ice Streams B and C. In Alley, R. B. and R. A. Bindschadler, eds. The West Antarctic ice sheet: behavior and environment. Washington, DC, American Geophysical Union, 257-281. (Antarctic Research Series 77.)

MS received 14 June 2000 and accepted in revised form 30 May 2001 